\title{
Henriette Stößl
}

Die Geistliche Kommunion der Heiligen Boris und Gleb: Exemplarische Rhetorik in einem polnischen Barockdrama. Köln; Weimar; Wien: Böhlau Verlag, 2013. Pp. 305, 15 black-and-white pictures. Hb, 39.9o Euros.

When it comes to Polish Jesuit Baroque drama, research is by no means abundant. This is partly due to the substantial loss of plays and manuscripts during the many wars that raged in Poland and Lithuania, but also due to difficulties in finding and identifying the manuscripts in the archives of Warsaw, Lublin, Poznań, and Vilnius, among others. Henriette Stößl sets out to narrow this gap by focusing on one particular play (Kommunia Duchowna S.S. Borysa y Hleba [The Spiritual Communion of Saints Boris and Gleb], written anonymously, performed c.1693) with a view to its rhetorical structure and its use of emblematic meaning. Although the text itself has been known and has also existed in edited form for some time (see Julian Lewański [ed.], Dramaty staropolskie, vol. VI [Warsaw: PIW, 1963]), it has not yet been interpreted in the contexts of its production, performance, and poetical character. Stößl locates her interpretation within a framework of emblem theory and concepts of intermediality (chap. 3), offering at the same time a thorough close reading of the drama (chaps. 4 and 5 ).

After situating her study within a tradition of research about emblematic interpretations of Baroque drama (mostly from the field of Slavic philology: Pelc, Okoń, Sofronova), the author intensely discusses theories on the interrelations of literature and the visual arts. While she only briefly touches on this topic in Jesuit poetic theory (referring, for example, to Jacob Masen, S.J.'s very influential Speculum imaginum veritatis occultae and Franciscus Lang, S.J.'s poetics), Stößl repeatedly refers to aesthetic theorists from the early twentieth century, such as Boris Uspenskij, Jan Mukařovský, Jan Białostocki, and Erwin Panofsky, to further illuminate the "anthropological ground of intermediality" (44-52). Although the reader might enjoy her overview, which arches from transcendental aesthetics (Kant) to more recent empirical approaches (Dewey), one might also note the absence of research on early modern and particularly Jesuit emblems as put forward by Peter M. Daly, to name only the most important representative. If I am not mistaken, there is only one reference to one of Daly's works to be found in Stößl's text $(264 n 72)$. At least the essential monograph of Albrecht Schöne (Emblematik und Drama im Zeitalter des Barock, $3^{\text {rd }}$ ed. [Munich: Beck, 1993]) is mentioned several times. The author does not seem to aim at a historicizing point of view on intermediality in the sixteenth and seventeenth centuries, but rather appears to argue for a timeless constant 
in the perception of works of art, visual or textual. By connecting the theories of Uspenskij, Panofsky, and the German church historian Konrad Onasch concerning literature as well as icon painting in the Eastern church, she is able to establish "common structural principles" (53) of visual and textual arts. But these principles have mostly been developed by a comparison of painting and narrative literature. Unfortunately, Stößl misses the opportunity to apply this theory to drama.

The reader finds this application implied in the subsequent analysis of the Kommunia Duchowna, which is covered in the monograph's main part. Stößl opens with a kind of second introduction, and it is only at this point that she illuminates the contemporary (i.e., seventeenth-century) context of literary theory in greater detail by quoting from and commenting on Maciej Kazimierz Sarbiewski (1595-1640) and his De perfecta poesi of 1626 (81-96). This is all the more welcome since, despite the fact that Sarbiewski and his works are very important not only for the Polish/Lithuanian but also for the European poetry and literary theory of his time, the amount of German and English research on him is comparatively small. Stößl inexplicably omits the most recent German publications on Sarbiewski, namely Eckart Schäfer (ed.), Sarbiewski. Der polnische Horaz (Tübingen: Narr, 2006) and chapters in: Volkhard Wels, Der Begriff der Dichtung in der Frühen Neuzeit (Berlin/Boston: de Gruyter, 2009). Sarbiewski's modifications of classical Aristotelian and earlier Jesuit poetics are as fascinating as his transfer of modern stage machinery (such as the mechanical psalterium and the laterna magica) from Rome, where he studied, to Jesuit schools in eastern Europe. Stößl's aim, however, is to find in Sarbiewski's poetics an early modern testimony for Uspenskij's "common structural principles" (i.e., modern intermediality), and she claims to have done so in the Jesuit's frequent comparisons of poetry and painting (92). One might wonder if this perspective of "ut pictura poesis" was more than a Horatian truism and an established topos in European poetics, but Stößl has a point when she interprets certain phrases by Sarbiewski, such as Virgil "being about to draw on his canvas of the epic poem a portrait of the perfect prince" [perfectissimi principis in tabula epopeae efficturus imaginem ], as more than examples of random metaphor. As far as Jesuit literary theory - as well as the rest of early modern Jesuit culture-is rooted in a particular estimation of picture, perception, and meditation (the Ignatian applicatio sensuum), the lines between visual and textual arts indeed seem to be blurred. This holds true especially for the Kommunia Duchowna, in which Stößl now detects textual and visual art, machinery, gesture, and performance as deeply intertwined. This observation, drawn from Sarbiewski, can indeed supplement and enrich other recent investigation into Jesuit "synaesthetical theory" (96-99). 
There can be no doubt that The Spiritual Communion of Saints Boris and Gleb is an interesting play in several respects. First, it is one of the few Jesuit plays from eastern Europe that has come to us almost intact. Second, it is written in the Polish language, although even at the end of the seventeenth century, most Jesuit school drama used Latin. And third, it probably stems from the college of Orsza at the Commonwealth's eastern borders (present-day Belarus), and therefore mixes Polish idioms (in the scenes) with several Russian and Ukrainian ones (in the prologues).

Turning to a detailed scrutiny of the play itself, Stößl gives a comprehensive summary of its four acts-definitely an advantage for those readers who do not read Polish. In this summary, she also hints at some basic dichotomies concerning main characters (Światopełk, who cunningly plans to murder his two brothers, vs. the legitimate heirs to the throne, Borys and Hleb) as well as relations between the central action and inserted scenes of comic relief (115, 196-220). The author develops her interpretation on the basis of four distinct elements: (a) author's point of view, (b) characters' point of view, (c) external point of view and framing, and (d) general composition and internal compositional structure. While dealing with the author's point of view, Stößl encounters some difficulties. Since the play was written by an anonymous author, she has to stick to an "implicit author." Furthermore, opportunities for a playwright within the early Society of Jesus to express "its own point of view" were greatly limited by guidelines and restrictions imposed by its superiors. Stößl quotes some of them $(130-32)$ but does not reflect on this topic. As in the previous theoretical introduction, the reader is faced with an at times irritatingly unsorted mixture of thoughts on rhetoric and drama. Anachronistically referring to theorists from the eighteenth to twentieth centuries, mainly Hegel and the Prague structuralist Jiř́ Veltruský, Stößl argues that drama is a synthesis of lyrical and narrative art and attempts to apply these "timeless and genre inherent qualities" (127; based on Husserl) to the Baroque drama as well — a doubtful enterprise at best, if one keeps in mind the substantially different systematization of genre used in early modern times. To name only one example, Stößl's argument that the Kommunia bears similarities to a lyrical text because it was written in verse (134f.) seems debatable. After all, this holds true for most tragedies and comedies since ancient times. The author's take on the characters' point of view turns out to be far more fruitful, since she is able to show some techniques of typecasting: the politically active tyrant Światopełk is recurrently characterized by anger [gniew] and cunning wit [dowcip], the latter quality incidentally being ascribed to the devil himself, who enters the stage in I, 5 . The mainly passive Saints Borys and Hleb, on the other hand, display qualities typical for the ethics of seventeenth-century Neo-Stoicism (constantia and tranquilitas animi, 
both of which virtues are transposed into a Christian context by frequent allusions to the crucifixion as well as the adoration of the Christ [176-79], while Swiatopełk imagines a blasphemous perversion of the Eucharist [193-95]). Stößl convincingly draws connections to Jesuit political theories, particularly the right to resist a tyrant, which was codified by Robert Bellarmine and Juan de Mariana (181-83). Most interesting are her frequent looks at the previously unpublished marginal notes in the play's manuscript (166f., 250), which seem to underline the importance of contrasting emotions in the typecasting of the main characters.

The "external point of view" is developed by analysing the play's paratexts. Stößl finds some analogous, at times even identical passages in prefaces to other plays transmitted in the Kodeks Orszański, which also holds the Kommunia Duchowna. This is an interesting observation that could shed some light on the (often very quick) production of plays in Jesuit schools. With the fourth part on "general composition," the author transitions to her main topic, rhetorical and emblematic structures in the Kommunia. Two choral interludes in the first act are interpreted as structural devices, along with two more or less complementary speeches by Borys's and Hleb's other brother, Jarosław. But this is not all. The moral imperative expressed in these verses, Stößl argues, qualifies them as the epigram to an emblem whose picture (pictura) is the plot itself $(228-31)$. Hence she interprets the whole drama in analogy to visual arts following the art historians Heinrich Wölfflin and especially Oskar Walzel, who in the early twentieth century applied Wölfflin's observations to Shakespeare's plays $(231-35)$.

Based on this - again, anachronistic - theoretical ground, the author displays the rhetorical and emblematical qualities of her exemplary play. Referring to more recent research by experts like Wilfried Barner, Sofronova, and Eugenia Ulčinaite, she examines the examples and sententiae throughout the play and plausibly shows the author's didactic strategies. Whenever she comments on the social circumstances of the play and its performance-the linguistic and cultural particulars of the Belorussian territory within the borders of PolandLithuania - the reader can sense the emergence of a history of Jesuit culture in central-eastern Europe $(155,241)$. Unfortunately, Stößl does not follow this trace but sticks to rhetorics and emblematics. Her observations in this field are solid overall, debatable only where her interpretation seems too narrow. When she claims that the author's use of mythological examples serves mainly to display his encyclopaedic knowledge, she underestimates the possible functions of that particular device. Światopełk, for example, justifies his plan to murder his brothers by referring to (among others) the mythological example of Medea, who killed Absyrtus to keep Jason safe. This allusion shows that the author 
knows not only Ovid, Euripides, and Seneca, but also his trade: by comparing himself to Medea, the tyrant exposes himself as being akin to the proverbial witch and murderess of early modern times. A few scenes later, Światopełk accordingly summons a magician to prepare a poisoned letter for Borys. Hence, the display of learnedness is supplemented by a moral imperative and an appeal to common mythological knowledge in order to further characterize the antagonist.

The monograph's last chapter on emblematic qualities $(251-67)$ luckily shows signs of leaving its theoretical framework behind and highlights three convincing examples of allusions to emblematic works within the play: Światopełk alludes to the notorious "Hercules Gallicus," his advisor Eryman compares the tyrant to a baby snake eating up its mother from within, and the reluctant heir Borys calls the Russian crown "regalia with a thorn." Stößl traces all three statements back to emblem books by Andrea Alciato, Joachim Camerarius, and La Perrière, but also reflects (as her most important reference, Albrecht Schöne, did) on the danger of jumping to conclusions: quoting a mythological name in a play does not necessarily invoke an emblematic context (257). Consequently, her final conclusion about how rhetorical qualities are more important for the play than emblematical ones seems coherent. Only a suspicious reader might be amazed that the initial idea of an emblematical structure organizing the whole play can be omitted so clandestinely.

Stößl is right to do so. And one might even ask the question of whether or not the extensive theoretical prefix was really necessary for the solid and detailed interpretation this book produces. After all, it offers fascinating insights into a part of neo-Latin literary culture in east-central Europe that deserves more profound case studies. This book makes a promising start in the right direction.

\author{
Jost Eickmeyer \\ University of Heidelberg \\ jost.eickmeyer@gs.uni-heidelberg.de \\ DOI 10.1163/22141332-00201005-08
}

